\title{
Svitlana Skvortsova
}

South Ukrainian National Pedagogical University named after K. Ushynsky, Odesa, Ukraine https://orcid.org/0000-0003-4047-1301

\section{Tetiana Britskan}

Izmail State University of Humanities, Izmail, Ukraine

https://orcid.org/0000-0001-7277-4169

\section{Organization of Mathematical Distance Learning in Primary School}

\begin{abstract}
The article is devoted to researching the problem of using ICT by primary school teachers in teaching mathematics, in particular during distance learning caused by the COVID-19 pandemic. The results of comparative analysis of the most common online services are presented in three categories: 1) services for creating a virtual classroom and interactive exercises and other educational content (LearningApps, Google Classroom, Classtime, and Classdojo); 2) services for organizing a distance lesson (Padlet); 3) services for conducting a distance lesson in the form of a conference (Zoom, Skype, Microsoft Teams). The generalized results of the online survey of Ukrainian primary school teachers on the use of these online services in mathematics lessons are presented. Furthermore, methodological recommendations for the use of selected online services are reflected in the developed e-course "Internet resources for creating mathematical learning and game content for primary schoolchildren".
\end{abstract}

K e y w or d s: ICT, distance learning, online services, primary schoolchildren 


\section{Using Online Services as a Means of Improving Learning Efficiency}

Based on the needs of modern students in a virtual environment, given the question of improving the effectiveness of learning, including mathematics in primary school, various scientists have researched the field of online services for teachers (Zegzula \& Smyrnova-Trybulska, 2017; Morze, Smyrnova-Trybulska, \& Boiko, 2019; Horvathova, 2019; Sagan, Los, Kazannikova, \& Raievska, 2019; Gocheva, Somova, Angelova, \& Kasakliev, 2020; Palaigeorgiou, Papadopoulou, \& Kazanidis, 2018; Razis, et. al., 2018; Afify, 2020; Kornytska, 2018; Stechkevych, 2020).

The use of various online services, in particular the online board Padlet, which allow for collaboration between students and the teacher have been explored by I. Kornytska (2018), while O. Stechkevich explores the possibilities of Google Classroom for the organization of the educational environment (Stechkevich, 2020).

Many researchers claim that interactive video has a positive impact on learning: (Palaigeorgiou, Papadopoulou, \& Kazanidis, 2018) and the learning environment created through interactive video has helped students achieve a high level of self-control, self-discipline, and self-learning, in addition to allowing them to manage their learning progress successfully. The results of Razis' study indicate that the use of interactive video improves the preservation of educational material in schoolchildren (Razis et. al., 2018). The results of Afify's study, on the other hand, showed that the performance of students who studied with the help of short videos achieved better results in both direct cognitive achievement and post-cognitive achievement, which is the preservation of learning outcomes in the long term (Afify, 2020). Finally, several researchers, such as Gocheva, Somova, Angelova, and Kasakliev emphasize that the game content created with the help of ICT is used both for cognitive activity and for motivating primary schoolchildren to learn mathematics and support understanding educational content (Gocheva, Somova, Angelova, \& Kasakliev, 2020).

It is also possible to increase the efficiency of teaching mathematics in primary school by using online services for teachers. Our research (Skvortsova \& Britskan, 2018, p. 59; Skvortsova, Onopriienko, \& Britskan, 2019, p. 277; Skvortsova, Britskan, Bastinec, \& Hruby, 2019, p. 74; Britskan \& Kovalchuk, 2019, p. 42; Britskan \& Fedii, Onopriienko, 2020, p. 9; Skvortsova, Ishchenko, \& Britskan, 2020, p. 124) focuses on preparing teachers to use Web 2.0 services: LearningApps, H5P, Plickers, GIMKIT, and Google Forms. Thus, LearningApps allows the teacher to create a virtual classroom, filling it with interactive tasks and recording the results of students' performance in a virtual journal. H5P does not give the teacher an 
opportunity to create a virtual classroom but, in this service, the instructor can develop a pre-prepared interactive educational video, providing pauses for students to perform interactive exercises created in the templates of this service. In Plickers, the teacher also does not have the opportunity to create a virtual classroom but it can be used to create test tasks with four possible answers and "true/false" quizzes. These quizzes are performed by students without the use of gadgets; they choose the correct answer to a particular task and raise printed cards with the appropriate side up. The teacher opens his own profile of this service in the gadget and scans all the cards at once. Plickers allows the teacher to create a series of different types of tasks, including tests and open-ended tasks, tasks using Google Forms, and send them to students for completion using a link. The advantage of creating tasks in this Google application is that the teacher can view the intermediate and final results of students performing the tasks. On the other hand, GIMKIT is a service for designing and instantly evaluating tests and quizzes. It should be noted that this service contains both a free version with a limited number of designs for creating quizzes and a paid one, which provides more opportunities for teachers. The GIMKIT service evaluates the performance of tests in the form of a game - by answering the questions correctly, the student "earns" money. The service contains three types of competition: 1) Game by game, where students compete individually for leadership; 2) Against their classmates, where students compete for leadership in the season, saving up "money" over a series of games; 3) Against other classes, where students compete collectively against other classes.

Mainly, our work contains practical recommendations for teachers on the use of these services, in particular in the process of teaching mathematics. We organized and conducted experimental training of teachers to work in these services and obtained results that prove the effectiveness of these Web 2.0 services in teaching primary schoolchildren (Skvortsova \& Britskan, 2018, p. 59; Skvortsova, Onopriienko, \& Britskan, 2019, p. 277; Skvortsova, Britskan, Bastinec, \& Hruby, 2019, p. 74; Britskan \& Kovalchuk, 2019, p. 42; Britskan, Fedii, \& Onopriienko, 2020, p. 9).

At the same time, the research study considered provides only general information on the use of a separate online service in the educational process. However, the issue of selecting online services for integrated use, including mathematics lessons in primary school, has escaped the attention of scientists. This prompted us to conduct research in this direction.

Based on the need for organizing distance learning caused by the COVID-19 pandemic and the inability of students around the world to attend school, we set the goal, thusly, to determine a set of online services for distance learning for use in math lessons and to explore which of these services are used by Ukrainian primary school teachers in math lessons. 


\section{Analysis of the Possibilities of Online Services for the Organization of Distance Learning}

To achieve the purpose of the study, at the stage of preparatory work, we explored the possibilities of free online services or services that provide a free version (Figure 1): LearningApps, Google Classroom, Classtime, Padlet, Zoom, Classdojo, Liveworksheets, Wizer.me, H5P, Lino it, etc.
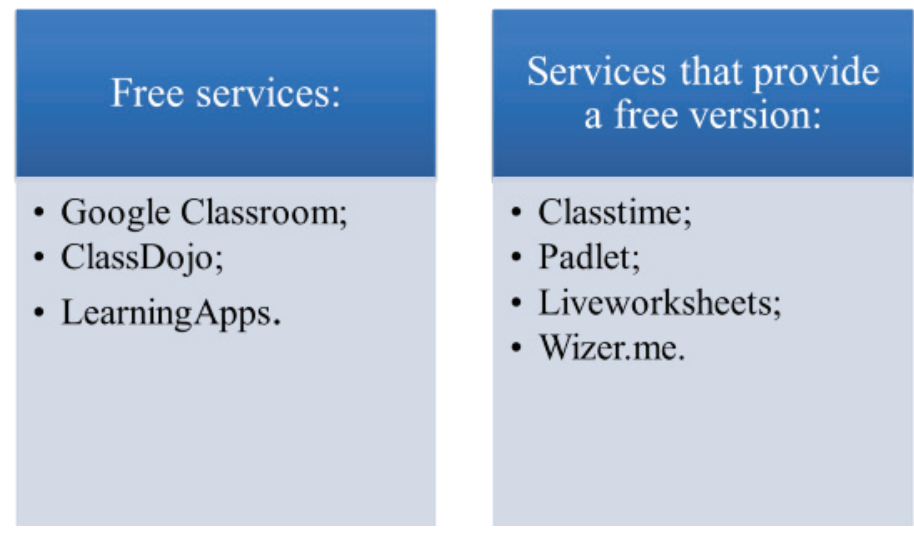

Figure 1. Paid and free online services.

S o u r c e: own work

For the organization of distance learning, the teacher needs to create a virtual classroom and invite students, fill this classroom with learning materials and tasks for students, preferably those that will be checked by the service automatically - making it interactive. It is important that the test results are recorded in the electronic journal in the form of a certain number of points; furthermore, it is also desirable that it stores the work of the students. When checking non-interactive tasks, the teacher needs the service to provide the teacher with feedback from students and parents, in the form of comments. The teacher is also interested in presenting all stages of the distance lesson in the online service. Therefore, an analysis of online services was carried out according to the following criteria: 1) availability of a virtual class and an electronic journal; 2) the ability to create materials and tasks, and export tasks from other services; 3 ) the possibility for the teacher to create interactive exercises on the basis of the tasks from the printed textbook or notebook; 4) service capabilities for organizing a distance lesson. 


\subsection{Organizing a Virtual Classroom and E-Journal}

When choosing services, we took into account the needs of teachers as regards digital tools for online teaching. To organize distance learning, the teacher needs a service that involves the creation of a virtual classroom where they can place tasks for students. We took into account the ease of connecting schoolchildren to the virtual classroom; the need or lack of registration on the site; the opportunity to create interactive exercises and tasks with open-ended questions; the ability to create tasks with links to other services; the opportunity for schoolchildren to send completed tasks; the opportunity to save schoolchildren's work and evaluate the results of their learning activities, both with points and verbally; and the opportunity to record test results in a virtual journal. After comparing online services that allow the teacher to create a virtual class and generate a virtual journal for inclusion in the e-course, we chose LearningApps, Google Classroom, Classtime, and Classdojo (Figure 2).

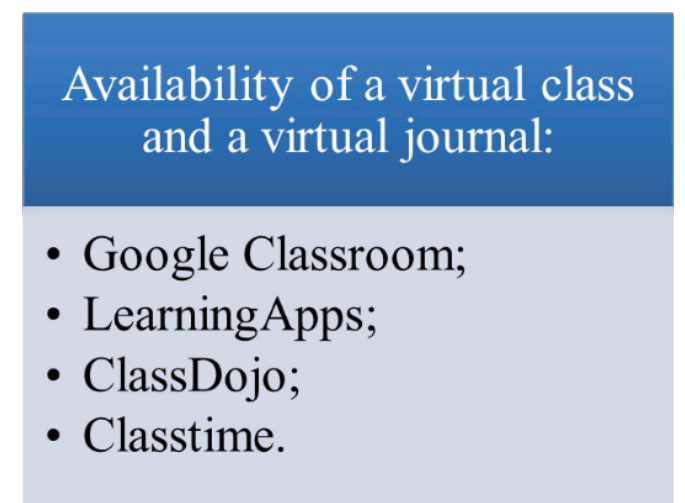

Figure 2. Services that provide the ability to create a virtual classroom and e-journal.

S o u r ce: own work

The ways of involving schoolchildren in a virtual classroom are shown in Figure 3 and the preferred ways to check completed tasks are shown in Figure 4.

In order to join students to the virtual class in LearningApps, the teacher fills in the profiles of all schoolchildren: indicates their names and surnames, and the service generates logins and passwords for them. Schoolchildren do not register on their own but attend the virtual classroom by following the link and typing in the login and password given to them by the teacher. After coming into the virtual classroom, the student views the pictures with the tasks to be completed and completes them in random order. But the student has only one attempt to perform a certain interactive task. Completed tasks are evaluated by the service 
automatically as completed/not completed. The students can review their results immediately after completion of the interactive exercise. The service allows the teacher to comment on the results of the task finished by a particular student. To do this, they need to go to the virtual class and select the option "Write a message" next to the appropriate name of the student.

\section{Self-registration on the site:}

- Google Classroom;

- Classtime.

\section{Registration on the site by the teacher:}

- LearningApps.

Invite schoolchildren to the service using an

e-mail:

- ClassDojo.

Figure 3. Ways of involving schoolchildren in a virtual classroom.

S o u r c e: own work

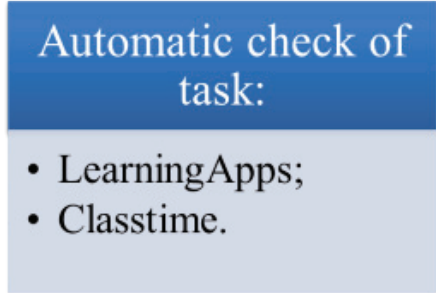

\section{The teacher checks the completed task:}

- ClassDojo;

- Google Classroom.

Figure 4. Ways to check tasks in selected services.

Sourc e: own work

The e-journal LearningApps contains a list of schoolchildren in the virtual classroom and a list of tasks that have been assigned. The results of the tasks performance are displayed in the following form: opposite the tasks that the student performed correctly, the service generates a mark with the word 'completed' in green, indicating the date and duration of time for this task. Tasks that are performed incorrectly are displayed in red. If a student has just opened an interactive exercise but has not completed it, this task is indicated with a yellow question mark. The pages of the e-journal can be printed out by the teacher immediately. 
Schoolchildren can only join a virtual classroom in the Google Classroom using their Gmail account and only with parental consent. Once in the created course, schoolchildren get acquainted with the learning material and complete tasks. The student's account displays a list of tasks, herewith the tasks downloaded by the teacher last, are located at the top of the list. The student can perform the tasks in any order. After completing the tasks, the student sends the work to the teacher in various formats - in the form of text, photos, Google images, audio, or video. The students can download the file from their own computer or give a link. Unlike LearningApps, the teacher checks the completed tasks (except for the test tasks created in Google Forms) and gives the appropriate grade awarding a certain number of points. Checking the task, the teacher can write a comment on the work or return the work for revision.

The Google Classroom e-journal, as well as the LearningApps e-journal, displays a list of students in the virtual classroom and a list of assignments given to students in the order they were uploaded by the teacher. The e-journal contains information about the tasks that students have submitted for review. By clicking on a specific task in front of a specific student, the teacher can view it, score according to his own criteria, and write a comment. Immediately, the number of points awarded by the teacher for the completed task and the maximum number of points are displayed in the electronic journal. The student, through e-mail box, is informed about the results of the teacher's check of his work. The teacher can view all assessment results in the journal and copy them to Google Spreadsheets or download them as a file (csv).

In the Classtime service, it is possible to create a virtual class with an electronic log of session results. In order to get students to the tasks, the teacher sends them a link and a session code. No special registration is required on the service. Once on the main page of the service, the student goes to the students' line and enters the code in the text box. Next, a window appears on the student's page where the student should write their last and first name. Then, the student gets to their own page, which displays the tasks they need to perform. According to the settings set by the teacher when creating tasks, the student has either only one attempt to complete the task or several. Unlike Google Classroom, where the teacher sets the maximum number of points for each task, in the Classtime service, like in LearningApps, the teacher cannot evaluate the completed task with points according to their own criteria. In the free version, the instructor has only two options - either 1 point or 0 points. Test tasks are evaluated by the service automatically and 1 point is awarded for the correct answer and 0 for the incorrect answer. There are tasks (Text template) which the teacher checks independently and awards with 1 point. 
The Classtime e-journal looks similar to the Learning Apps e-journal. Opposite the task that the student has completed correctly, the mark is displayed in green, incorrectly completed tasks - in red. Unlike LearningApps and Google Classroom, the Classtime service calculates the total score for all tasks completed by the student. In the free version of the service, the instructor can download the analysis of results only in a pdf document and in the paid version - in Excel.

In Classdojo, teachers invite students to a created class, similar to the Google Classroom, by adding their e-mail boxes to the list. The service sends them invitations by mail. Similar to Classtime and LearningApps, students can also join their class by typing in their class's entry code. There is also an opportunity for students to enter into the virtual classroom by scanning the QR code. Once in the classroom, students choose an avatar in the form of a monster that will represent their profile. Tasks for the student are performed in the Portfolio tab and information materials - in the Class Story tab. Tasks are presented in the form of a list and the student must complete them in the order they were prepared by the teacher; at the bottom of the list, there are the tasks that were created by the teacher last. The format of the student's answer, whether it is text, drawing, audio or video, is indicated by the teacher in advance when creating the task. It is not possible to submit a response in another format, or in multiple formats, unlike in Google Classroom. So, if the teacher, during the development of the task, stated that the answer should be sent in the form of a video, then, starting the task, the student will immediately turn on the camera on their device.

The teacher checks completed tasks independently. For each task, the teacher does not give points but skills. Moreover, skills are designed by the teacher themselves, giving them a name and scoring from 1 to 5 points. Parents of all students can be invited to the service and the results of their children's learning activity can be shared with them so parents can monitor the success of their children's academic performance and communicate with the teacher.

There is no e-journal in the Classdojo service like in LearningApps, Google Classroom, and Classtime. After the students have completed the tasks, the teacher can view each student's portfolio with the completed tasks, which is evaluated with skills (from 0 to 5 points) and download the results to their own computer in the form of a journal in Microsoft Excel (.csv) file or in Google Spreadsheets. Thus, there is no e-journal in this service; it is only possible to download the results of students' work on the tasks to the teacher's computer, which will allow them to view the results of students in the usual format.

Based on this, the authors have selected online services LearningApps, Google Classroom, Classtime, and Classdojo for the e-course which allowed for the creation a virtual class, filling it with tasks for students; these were services that automatically generate a virtual journal or allow the teacher to download it to their 
computer. But, to organize distance learning, the authors are interested in the Padlet virtual board, which does not involve the creation of a virtual classroom and a virtual journal but only groups the users of the virtual board. This board is interesting due to the variety of board templates, the ability to present all elements of the lesson on a virtual board, the variety of forms of presenting lesson tasks - its images, photos, videos, audio, text, and embedding links to other online services and other Internet content. Although it groups users on a virtual board, an analogue of the virtual classroom, it does not allow students to send completed tasks; students can only comment on the tasks presented on the virtual board and these comments can be read by all users of the virtual board. The format of students' comments is either text, audio, video, images, and/or photos.

\subsection{Organizing Distance Learning}

As a result of the analysis of LearningApps', Classtime's, Google Classroom's, Classdojo's, and Padlet's opportunities, the conclusion has been reached that, to organize distance learning, it is expedient to choose Google Classroom as a basic service. This service allows the teacher to create a virtual class and has a convenient virtual journal. Google Classroom involves filling the lesson not only with tasks, but also materials that are not subject to evaluation. In the materials section, the teacher can give students a link to the Padlet virtual board that will present the lesson in the form of a scheme with arrows (virtual board canvas), according to which all stages of the lesson are organized - greeting the teacher, updating basic knowledge and methods of action, the formation of new knowledge and methods of action, as well as skills' consolidation and formation, and, finally, the result of the lesson and reflection on it. The choice of the Padlet virtual board for presenting a lesson is also explained by a variety of forms of task presenting - video and audio, drawings, interactive tasks created in LearningApps service, the link to Classtime, Classdojo, and other services. The only inconvenience is that students cannot send their answers to this service - they have to send them in Google Classroom. Therefore, in the virtual classroom, the tasks for students presented on the Padlet virtual board are duplicated, and the tasks are filled in the same order as they are offered in the lesson in Padlet. We would like to note that Google Classroom practically does not allow the teacher to create interactive tasks so, in Google Classroom, students will send either photos or screenshots of interactive tasks performed in other services, such as LearningApps or Classtime. The teacher checks the student's work himself: according to the screenshot of interactive tasks uploaded to Google Classroom, they are awarded a certain number of points and open-ended tasks are checked on their own. Moreover, a very useful function is that the teacher can comment on the tasks performed by students in order to draw students' attention to mistakes. 
Presenting a lesson on the Padlet virtual board with duplicated interactive exercises in the Google Classroom task list creates the conditions for distance learning at a time convenient for the students. But, if it is possible to organize distance learning at a certain time, according to the schedule, then, in this case, the teacher is more interested in services that allow them to organize conferences. These can be Skype, Zoom, or Teams.

To begin with, Skype is a free program to download. To create an online lesson, the teacher generates a link and students use it to join the lesson. The teacher must also share the link by inviting all students, even if they are not Skype subscribers. A student can join an online lesson in a browser window if they do not have the program installed. A maximum of 50 people can be invited to one lesson and there is no limit to the duration of the call. In this program, there is an opportunity to show the screen to the moderator and conference participants. The teacher can also make a video of the conference, which is stored up to 30 days. An additional feature in this service is that background blur can be enabled so that nothing extra gets into the frame.

In contrast, Microsoft Teams combines meeting chat, file sharing, and corporative applications in a common desktop environment. There are paid and free versions; this application can be used by the whole educational institution, which expands the possibilities of its use. The duration of the broadcast of Microsoft Teams is 24 hours. In this program, there is an opportunity to show the screen to the moderator and conference participants.

Lastly, Zoom offers communication software that combines video conferencing, online meetings, chat, and mobile collaboration. There are paid and free versions. Prior to quarantine, the free one allowed for short 40-minute video conferences. For the duration of the pandemic, this restriction has been removed.

Thus, as a result of the analysis of online services on the criteria of free version's availability, the ability to create virtual classrooms, filling it with tasks, and the availability of a virtual journal, the ability to submit all elements of the lesson, and online conferencing organization, for the organization of distance learning, we selected online services: Learning Apps, Google Classroom, Classtime, Padlet, Classdojo, and Zoom. Therefore, we were interested in the issue of awareness of primary school teachers about the existence of these services and their use in teaching mathematics to pupils. 


\section{Experimental Study of the Use of Online Services by Primary School Teachers in Ukraine}

\subsection{Purpose, Tasks, and Tools of the Study}

The aim of the study was to determine the set of online services that primary school teachers worked with during the quarantine caused by the COVID-19 pandemic in March-May 2020. In the process of experimental research, the following tasks were solved: 1) the creation of the list of online services of which teachers are aware is determined; 2) naming online services that teachers have worked with; 3) the identification of online services that teachers used to organize a virtual classroom; 4) the identification of online services that teachers used to create interactive exercises in mathematics and other electronic materials; 5) the identification of online services that teachers used to organize and conduct an online lesson; 6) determination of what services teachers used when creating an educational video; 7) analysis of the obtained experimental data and identification of online services which were the most popular among teachers; 8) the comparison of the results of experimental research with the results of the preparatory one - the theoretical part of the study is used to determine a set of online services for the organization of distance learning of mathematics for primary school students.

\subsection{The Results of a Survey of Ukrainian Primary School Teachers on the Use of Online Services}

The main method of the experimental part of the study was a survey of Ukrainian primary school teachers. To study the problem of primary school teachers' use of the online services discussed above, we organized an online survey of Ukrainian teachers. This survey is posted in the closed group on Facebook called "Mathematics 'Ranok'. Pilot" (Figure 5), which was created for the professional communication of primary school teachers.

This group has 9,277 participants - mostly primary school teachers, as well as teachers of pedagogical universities of Ukraine and students majoring in "Primary Education". The settings of the group make it possible to create a survey, the results of which are immediately analyzed by Facebook and presented in the form of a diagram, which shows even the avatars of teachers who gave particular answers. Unfortunately, this survey format does not make it possible to determine the exact number of teachers who took part in the survey, as one and the same teacher could choose several answers. In addition, each question was presented in a separate publication so we have a different number of answers to different questions. In summary, it can be stated that at least 119 teachers answered at least one question 
of the survey (this is the largest number of teachers who chose one of the options to answer at least one of the survey questions).

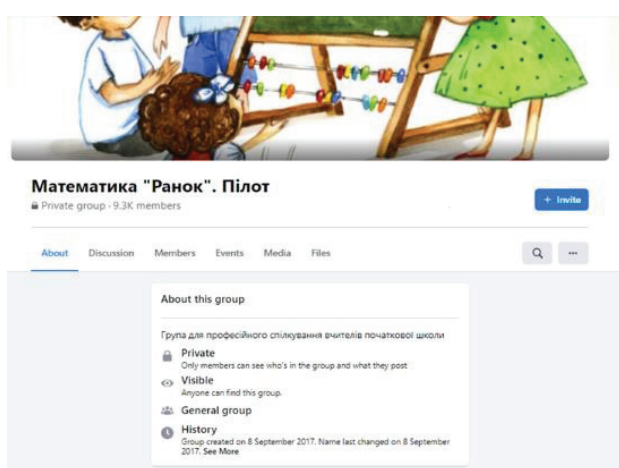

Figure 5. Page of the group "Mathematics 'Ranok'. Pilot".

S o u r c e: Facebook, https://www.facebook.com/groups/114415665917818

The group members were asked to answer six multiple-choice test questions. Each question was offered answer options but survey participants had the opportunity to add their own answers.

The questions were preceded by a brief explanation of the purpose of the survey: "Dear colleagues! We investigate the problem of the use of ICT by primary school teachers in teaching mathematics to pupils. We ask you to answer the following questions. Choose one or more answers to the question, and, if necessary, add your own answer. Thank you for your cooperation!".

The first question was: "Which of the online services for distance learning do you know?". In answering this question, teachers had to name the services they were aware of, whether their colleagues were working with or whether they had heard about these services from colleagues or on the Internet. The distribution of teachers' answers is presented in Figure 6.

As can be seen, the most popular is Viber/Messenger; this answer was chosen by $23 \%$ of teachers. Slightly fewer teachers are aware of Google Classroom $-21 \%$ of teachers, and LearningApps $-18 \%$ of teachers. Less popular among teachers are the following services: Padlet $-11 \%$ of teachers, Classdojo $-9 \%$ of teachers, Classtime $-5 \%$ of teachers, Liveworksheets $-4 \%$ of teachers, Wizer.me $-2 \%$ of teachers, Learnis $-2 \%$ of teachers, $\mathrm{H} 5 \mathrm{P}-1 \%$ of teachers, and Lino.it $-1 \%$ of teachers. Survey participants also had the opportunity to add their answer options. Yes, the teachers added Plickers to the first question and $2 \%$ of respondents indicated that they also worked with this service; Google Meet was indicated by $1 \%$ of teachers. 
Organization of Mathematical Distance Learning in Primary School

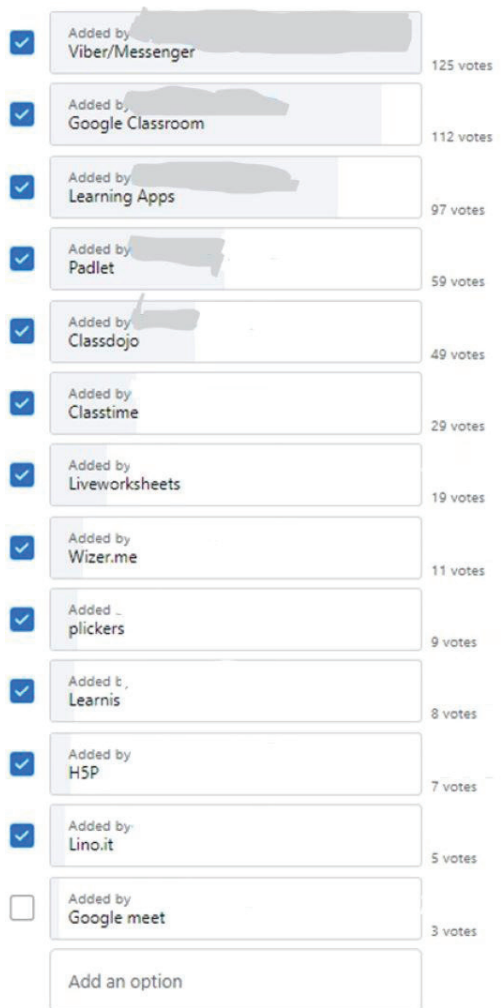

Figure 6. The results for the question "What services do you know?"...

S o u r c e: Facebook survey. https://www.facebook.com/groups/114415665917818/permalink/61359 1862666860

Thus, primary school teachers in Ukraine are generally aware of online services that can be used in the organization of mathematics' distance learning.

The next question was to discover which services the teachers worked with or continue to work with (Figure 7).

Here, fewer answers were received but the pattern of the greatest popularity of Viber/Messenger remained $-24 \%$ of votes. Zoom and Google Classroom are about equally popular with teachers; they received $18 \%$ of votes and $16 \%$ of votes, respectively. The ranking of online services that teachers have worked with or continue to work with is distributed as follows: LearningApps $-10 \%$ of votes, Padlet $-7 \%$ of votes, Classdojo $-4 \%$ of votes, Classtime $-2 \%$ of votes, Learnis $-2 \%$ of votes, Liveworksheets $-2 \%$ of votes, Lino.it $-1 \%$ of votes, Wizer.me $-1 \%$ of votes, and $\mathrm{H} 5 \mathrm{P}-1 \%$ of votes. If the answers are compared between question 1 and question 2, we can see that 112 teachers know about the existence of Google Classroom but only 40 teachers work with it; 97 teachers know about LearningApps but only 25 
use it; 59 teachers know about the Padlet virtual board but 19 teachers are used; 49 teachers know about the Classdojo service but only 11 teachers used it; 29 people know about the Classtime service but only 5 teachers used this service; 19 teachers know about Liveworksheets service but only 5 used this program; 11 people know about the Wizer.me service and only 1 teacher used it; 8 teachers knew about Learnis and 4 teachers used it; 7 teachers know about the H5P service and only 1 teacher uses it; 5 people know about Lino.it service but only 2 teachers use it. This state of affairs can be explained by the fact that the first and second questions were answered by different numbers of teachers; perhaps there were those who answered only the first question.

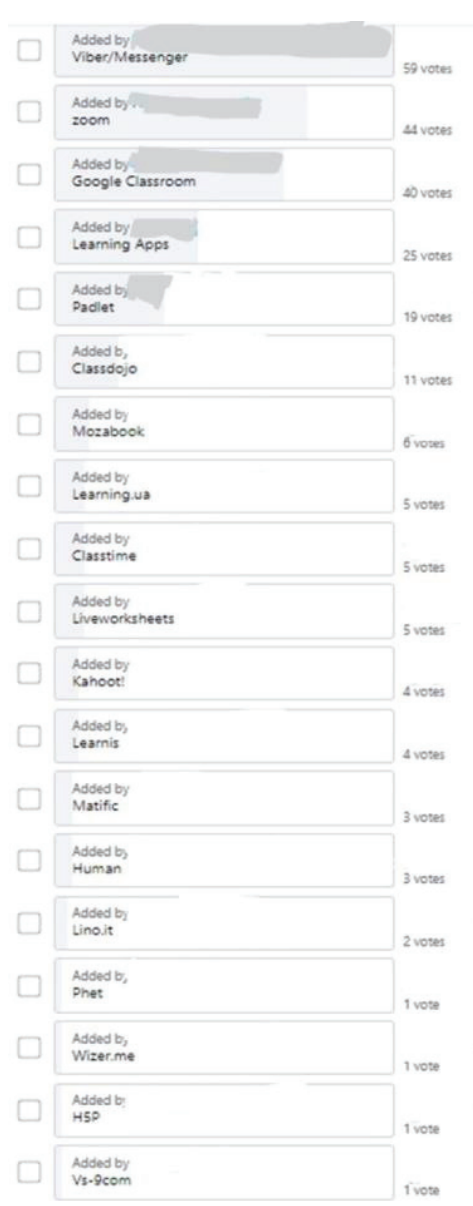

Figure 7. The results for the question "What services have you worked with or continue to work with?".

Source: Facebook survey. https://www.facebook.com/groups/114415665917818/permalink/613594019333311 
Note that teachers added other services in the answer to the second question. And these are Mozabook $-2 \%$ of votes, Learning.ua - $2 \%$ of votes, Kahoot! $-2 \%$ of votes, Matific $-2 \%$ of votes, Human $-2 \%$ of votes, Phet $-1 \%$ of votes, and Vs-9com $-1 \%$ of votes. We can conclude that each teacher chooses the service that meets most of their needs.

Thus, primary school teachers in Ukraine mostly use Viber/Messenger, Zoom, Google Classroom, and LearningApps in teaching mathematics.

The third question involved choosing an online service to conduct an online lesson (Figure 8). Most teachers cast their votes for Zoom (82\% of votes). Google Meet received $12 \%$ of votes, Skype $5 \%$ of votes, and Microsoft Teams $1 \%$ of votes. The results are predictable, as most teachers preferred the service which has a free version despite some time constraints on conducting an online lesson.

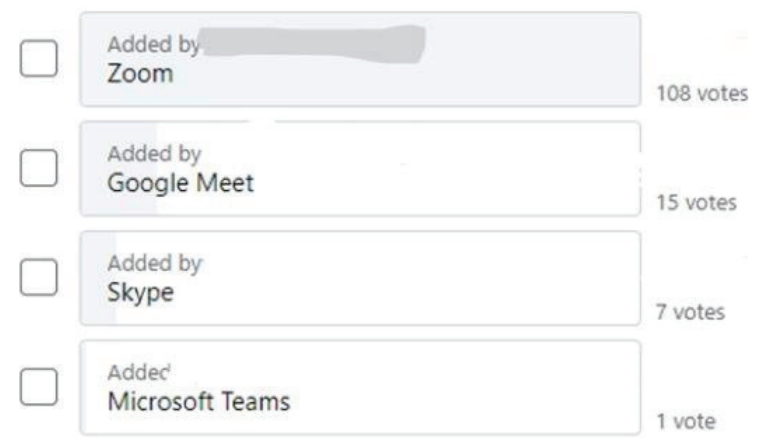

Figure 8. The results for the question "What services do you use to conduct an online lesson?".

S o u r c e: Facebook survey. https://www.facebook.com/groups/114415665917818/permalink/61359549 5999830

In answering the fourth question, teachers chose the services they use to create interactive exercises and teaching materials and tasks (Figure 9). The most popular service is LearningApps; $44 \%$ of teachers mentioned it in their answers. $21 \%$ of teachers marked Google Classroom, 15\% of teachers - virtual board Padlet, $6 \%$ of teachers - Classtime, $6 \%$ of teachers - Classdojo, $1 \%$ of teachers - H5P, and $1 \%$ of teachers - Lino.it. In addition, teachers added the following answer options: Kahoot! and $6 \%$ of respondents indicated that they, among others, also use this service. Liveworksheets, Wizer.me, and Learnis received no votes. It means that teachers do not have knowledge about the capabilities of these services and they have unformed skills to work with them. Although these services have quite a lot of features - they allow an instructor to make almost any task that can be made in a notebook - it additionally features an interactive printer base, as well as a possibility to create a training video with pauses to complete tasks. Thus, 
we can conclude that the surveyed teachers have no experience with interactive emails, interactive videos, and web quests. And this raises some concerns about the readiness of Ukrainian primary school teachers to organize distance learning for a possible extended quarantine period.

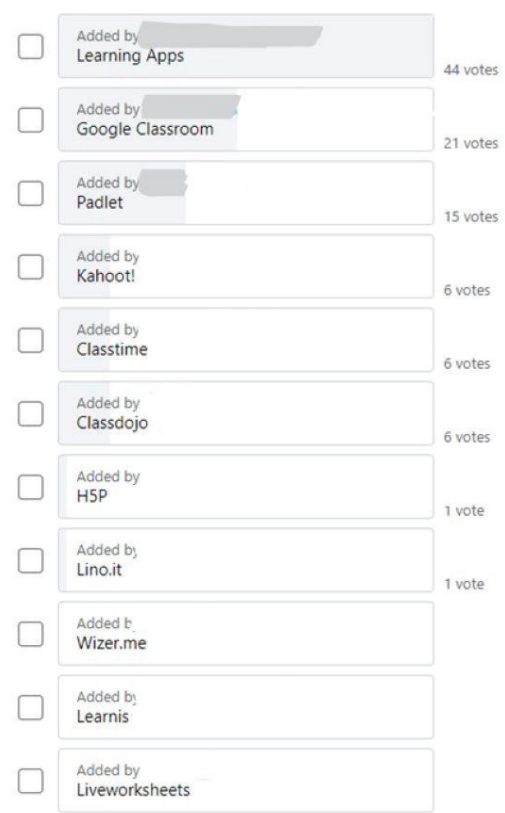

Figure 9. The results for the question "What services do you use to create interactive exercises, fill the course with educational materials and tasks?".

S o u r c e: Facebook survey. https://www.facebook.com/groups/114415665917818/permalink/613598 155999564

Because instructional videos with teacher explanations play a role in distance learning, teachers were asked the fifth question. In answering this question, teachers had to indicate whether they have experience in creating educational videos and if so, what services they use for this purpose (Figure 10). $84 \%$ of teachers indicated that they have experience in creating educational videos: $51 \%$ use Microsoft PowerPoint, 29\% record videos in Zoom, and 3\% of teachers in Learnis. Teacher R. Boyko also pointed out that she uses a set of services to create an educational video: Zoom + Freecam (1\%). 16\% of teachers indicated that they had no experience creating educational videos.

In order to answer the sixth question, teachers had to choose the services they use to organize a virtual classroom and an e-journal (Figure 11). 54\% of teachers chose Google Classroom, 18\% of teachers - LearningApps, $16 \%$ teachers - vir- 
tual board Padlet, $6 \%$ teachers - Classdojo, 2\% of teachers - Classtime, and $1 \%$ of teachers - vs-9com. Moreover, teachers added the Human service to this question and $2 \%$ of respondents indicated that they also worked with it. Also, $1 \%$ of respondents indicated that they organize a virtual classroom and e-journal using their own school platform at school.academy.com.ua.

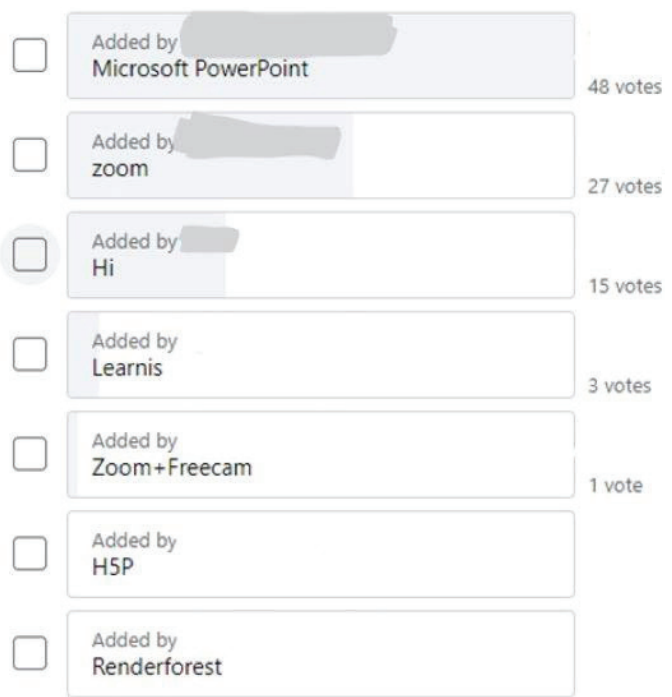

Figure 10. The results for the question "Do you have experience in creating an educational video? If so, what services do you use?"

S o u r c e: Facebook survey. https:/www.facebook.com/groups/114415665917818/permalink/6136005 09332662

Thus, primary school teachers in Ukraine are familiar with most online services that can be used to organize distance learning. But, for now, they are limited to creating a virtual class and have appreciated the benefits of a virtual journal in Google Classroom. At the same time, not many teachers create interactive math exercises and only 3 teachers use the Learnis service to create interactive videos. It is in these areas, in the direction of learning to create interactive tasks, "live" sheets, and interactive educational videos, that it would be advisable to work with Ukrainian primary school teachers.

The results of the survey confirm our opinion that, for the organization of distance learning, it is advisable to choose Google Classroom as a basic service. This service is the most common among teachers and they have experience working with it. One of the many advantages of this program, among others, is that an instructor can organize a distance lesson in this service by following the link to the virtual Padlet board, which presents all stages of the lesson, with 
materials and tasks created in the services LearningApps, Classtime, Classdojo, and others.

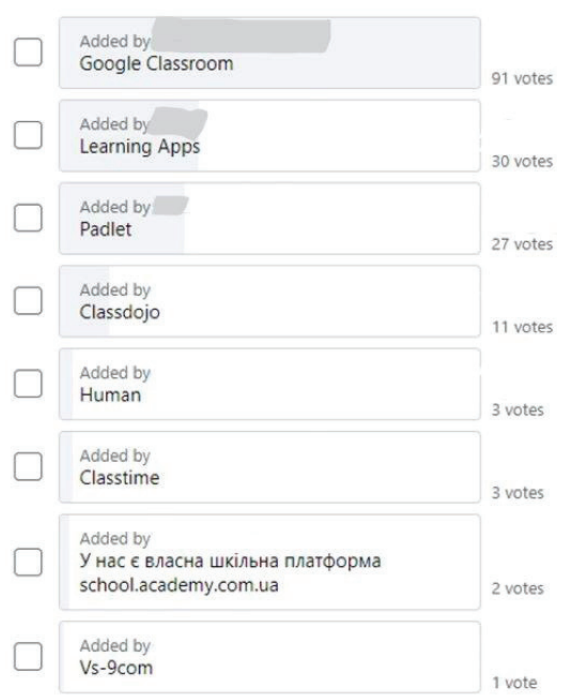

Figure 11. The results for the question "What services do you use to organize a virtual classroom and e-journal?".

S o u r c e: Facebook survey. https://www.facebook.com/groups/114415665917818/permalink/61359 6325999747

\section{Conclusions}

We should state that there are a lot of various services on the Internet that can be used to teach primary schoolchildren. But each service has its own peculiarities in terms of functioning and involves both advantages and disadvantages of its use in the educational process, in particular for the organization of distance learning. It should also be noted that there is no single service that can completely satisfy the teacher - the one used to create a virtual classroom and organize various tasks students are assigned, and to evaluate and store schoolchildren's work and track the dynamics of their success in the virtual journal. Therefore, to organize the learning process, the teacher must use a set of online services.

The authors studied the possibilities of free online services or services that provide a free version: LearningApps, Google Classroom, Classtime, Padlet, Zoom, Classdojo, Liveworksheets, Wizer.me, H5P, Lino it, etc.; both the advantages and 
disadvantages of their use in teaching mathematics to primary schoolchildren were outlined. The peculiarities of presenting mathematical problems with the help of various templates of these services were analyzed. The aspect of combining these services was considered and the question which services can complement or replace each other was discussed.

Based on the criteria set forth earlier for the analysis of online services, namely: 1) the availability of a virtual classroom and 2) organization and functionality of the e-journal, along with an analysis of survey data of Ukrainian primary school teachers, we consider it appropriate to conduct special work to familiarize them with or improve their skills in working with the following online services: LearningApps, Google Classroom, Classtime, Padlet, Classdojo, and Zoom. These services allow the teacher to organize distance learning of mathematics for primary schoolchildren taking into account the aspects outlined above.

For the organizational structure, the authors advise an instructor to choose the most popular service among teachers, namely Google Classroom, which is easy for schoolchildren to access through a Google account. This service offers a convenient format of the virtual class in the form of a list of tasks with the specified deadline of their performance and the maximum score. Google Classroom is a very informative e-journal, where the teacher can award points for the task, and all student works are stored in it. The only inconvenience of the Google Classroom service is the rather limited possibilities of creating interactive exercises, but there is a possibility to embed links to other online services. In addition to the tasks assessed by the teacher, teaching materials for the lesson can also be created, which will not be recorded in the electronic journal.

As training material, the authors recommend that the teacher provide a link to the lesson presented on the Padlet virtual board. The Padlet virtual board allows the teacher to display all stages of the lesson, presenting each element in a variety of formats (text, picture, audio, video, links to other content). It is not possible to create interactive tasks in this service, but interactive exercises from other services, such as LearningApps can be embeded. Schoolchildren complete the LearningApps task and send a screenshot in response to the virtual Google Classroom. Therefore, all the tasks presented on the virtual board should be duplicated in the list of tasks in the virtual classroom. Students' works are reviewed by the teacher in Google Classroom, and their results are instantly displayed in an e-journal.

These services are included in the program of e-course "Internet resources for creating mathematical learning and game content for primary schoolchildren". The authors see prospects for further research in continuing to study the peculiarities of other online services, which can also be used to create educational and game content in mathematics for primary schoolchildren and develop the next course for primary school teachers of Ukraine. 


\section{References}

Afify, M. K. (2020). "Effect of interactive video length within e-learning environments on cognitive load, cognitive achievement and retention of learning." Turkish Online Journal of Distance Education-TOJDE, 21(4), 68-89. https://dergipark.org.tr/en/download/article-file/1321142

Britskan, T., \& Kovalchuk, I. (Eds.) (2019). Vykorystannia servisu GIMKIT na urokakh matematyky $\mathrm{v}$ pochatkovii shkoli. Proceedings from the Materials of All-Ukrainian scientific-practical conference "Innovative solutions in primary school: experience in implementing the concept of the New Ukrainian School." Poltava V.G. Korolenko National Pedagogical University.

Britskan, T., Fedii, O., \& Onopriienko, O. (Eds.) (2020). Yspolzovanye Google Forms na urokakh matematyky v nachalnoi shkole. Proceedings from the Materials of International scientificpractical conference "Innovative teaching techniques in physics, mathematics, vocational and mechanical training." Mozyr State Pedagogical University.

Gocheva, M., Somova, E., Angelova, V., \& Kasakliev, N. (2020). Types of mobile educational games for children in primary school. Proceedings from the Materials $14^{\text {th }}$ International Technology, Education and Development Conference (INTED 2020). https://www.researchgate.net/ publication/340120432_TYPES_OF_MOBILE_EDUCATIONAL_GAMES_FOR_CHILDREN_IN_PRIMARY_SCHOOL

Horvathova, V. (2019). Exploring addition and subtraction strategies with virtual manipulatives on tablet devices in second grade. In E. Smyrnova-Trybulska (Ed.), E-learning and STEM Education. Series on E-learning. Vol. 11 (pp. 321-333). Studio Noa for University of Silesia. https://us.edu.pl/wydzial/wsne/wp-content/uploads/sites/20/Nieprzypisane/E-learning-andSTEM-Education-2019-Vol.11.pdf

Kornytska, I. A. (2018). Rozvytok piznavalnoi aktyvnosti uchniv pochatkovykh klasiv zasobamy navchalnykh onlain-servisiv. Young Scientist, 3(55), 551-554. http://www.irbis-nbuv.gov. ua/cgi-bin/irbis_nbuv/cgiirbis_64.exe?I21DBN=LINK\&P21DBN=UJRN\&Z21ID $=\& S 21 R E$ $\mathrm{F}=10 \& \mathrm{~S} 21 \mathrm{CNR}=20 \& \mathrm{~S} 21 \mathrm{STN}=1 \& \mathrm{~S} 21 \mathrm{FMT}=\mathrm{ASP} \_$meta\&C21COM=S\&2_S21P03 $=\mathrm{FILA}=\& 2$ $\mathrm{S} 21 \mathrm{STR}=$ molv_2018_3(2)__36

Morze, N., Smyrnova-Trybulska, E., \& Boiko, M. (2019). The impact of educational trends on the digital competence of students in Ukraine and Poland. In E. Smyrnova-Trybulska (Ed.), Elearning and STEM Education. Series on E-learning. Vol. 11 (pp. 365-379). Studio Noa for University of Silesia. https://us.edu.pl/wydzial/wsne/wp-content/uploads/sites/20/Nieprzypisane/ E-learning-and-STEM-Education-2019-Vol.11.pdf

Palaigeorgiou, G., Papadopoulou, A., \& Kazanidis, I. (2018). Interactive Video for Learning: A Review of Interaction Types, Commercial Platforms, and Design Guidelines. Proceedings from the International Conference on Technology and Innovation in Learning, Teaching and Education, 503-518.

Razis, S. N. I. M., Radzuan, L. E. M., \& Manan, J. (2018). Improving Teaching and Learning Module Through Implementation of Mnemonic Method and Interactive Video for Subject of History Studies. Proceedings from the Art and Design International Conference (AnDIC 2016), 431-435.

Sagan, O., Los, O., Kazannikova, O., Raievska, I. (2019). A system of effective task in blended learning on the basis of bloom's taxonomy. In E. Smyrnova-Trybulska (Ed.) E-learning and STEM Education. Series on E-learning. Vol. 11 (pp. 171-187). Studio Noa for University of Silesia. https:/us.edu.pl/wydzial/wsne/wp-content/uploads/sites/20/Nieprzypisane/E-learning-andSTEM-Education-2019-Vol.11.pdf

IJREL.2021.7.1.06 p. 20/23 
Skvortsova, S., \& Britskan, T. (2018). Training for future primary school teachers in using service learning apps teaching mathematics. International Journal of Research in E-learning (IJREL), 4(1), 59-77. http://www.ijrel.us.edu.pl/sites/default/files/2020-01/4.Training\%20for\% $\% 20 \mathrm{Fu}-$ ture\%20Primary\%20School....pdf

Skvortsova, S., Britskan, T., Bastinec, J., \& Hruby, M. (Eds.) (2019). Training for primary school teachers in using service Plickers teaching mathematics. Mathematics, information technologies and applied science (post-conference proceedings of extended versions of selected papers), June 20-21, 2019. - Brno, 74-87. http://mitav.unob.cz/data/Mitav2019.pdf

Skvortsova, S., Ishchenko, A., \& Britskan, T. (2020). Using of information and communication technologies in the primary school teacher's professional activity. Series of monographs Faculty of Architecture, Civil Engineering and Applied Arts, Katowice School of Technology, 124-135. http://www.wydawnictwo.wst.pl/uploads/files/0ad120790b2aa998c7ddee02f44f6deb.pdf

Skvortsova, S., Onopriienko, O., \& Britskan, T. (2019). Training for future primary school teachers in using service H5P teaching mathematics. In E. Smyrnova-Trybulska (Ed.), E-learning and STEM Education. Seria on E-learning. Vol. 11 (pp. 277-294). Studio Noa for University of Silesia. http://www.studio-noa.pl/doi/e-learning/11/el-2019-11-18.pdf

Stechkevych, O. O. (2020). Zabezpechennia zvorotnoho zviazku zasobamy Google Classroom $\mathrm{u}$ protsesi dystantsiinoho navchannia. Proceedings from the Collection of scientific works ИОГОГ. https://doi.org/10.36074/15.05.2020.v4.17

Zegzula, D., \& Smyrnova-Trybulska, E. (2017). Informational technologies in the operation of primary schools. In E. Smyrnova-Trybulska (Ed.), Effective Development of Teachers' Skills in the Area of ICT and E-learning. Series on E-learning. Vol. 9 (pp. 331-346). Studio Noa for University of Silesia. https://us.edu.pl/wydzial/wsne/wp-content/uploads/sites/20/Nieprzypisane/Effective-Development-of-Teachers\%E2\%80\%99-Skills-in-the-Area-of-ICT-and-Elearning.pdf.pdf

Svitlana Skvortsova, Tetiana Britskan

\title{
Organizacja nauki na odległość z matematyki w szkole podstawowej
}

\author{
Streszczenie
}

Artykuł poświęcony jest badaniu problemu wykorzystania technologii informacyjno-komunikacyjnych przez nauczycieli szkół podstawowych w nauczaniu matematyki uczniów szkół podstawowych, w szczególności w nauczaniu na odległość spowodowanym pandemią COVID-19. Przedstawiono wyniki analizy porównawczej najpopularniejszych usług internetowych w trzech kategoriach: 1) usługi tworzenia wirtualnej klasy i wypełniania jej interaktywnymi ćwiczeniami oraz innymi treściami edukacyjnymi (LearningApps, Google Classroom, Classtime, Classdojo), 2) usługi związane z organizacją lekcji na odległość (Padlet); 3) usługi prowadzenia lekcji na odległość w formie konferencji (Zoom, Skype, Microsoft Teams). Przedstawiono uogólnione wyniki ankiety internetowej przeprowadzonej wśród nauczycieli szkół podstawowych na Ukrainie na temat korzystania z określonych usług online na lekcjach matematyki. Zalecenia metodyczne dotyczące korzystania z wybranych serwisów online znajdują odzwierciedlenie w opracowanym kur-

IJREL.2021.7.1.06 p. 21/23 
sie elektronicznym ,Zasoby internetowe do tworzenia treści edukacyjnych i gier z matematyki dla młodzieży szkolnej”.

S łow a kluc z ow e: TIK, kształcenie na odległość, usługi online, młodzież szkolna

Светлана Скворцова, Татьяна Брицкан

\section{Организация дистанционного обучения математики в начальной школе}

А ннот а ция

Статья посвящена исследованию проблемы использования учителями начальных классов ИКТ в обучении младших школьников математике, в частности при дистанционном обучении, вызванного пандемией COVID-19. Представлены результаты сравнительного анализа наиболее распространенных онлайн сервисов по трем категориям: 1) сервисы для создания виртуального класса, и его наполнения интерактивными упражнениями и другим учебным контентом (LearningApps, Google Classroom, Classtime, Classdojo), 2) сервисы для организации дистанционного урока (Padlet); 3) сервисы для проведения дистанционного урока в виде конференции (Zoom, Skype, Microsoft Teams). Представленные обобщенные результаты онлайн опроса учителей начальной школы Украины относительно использования указанных онлайн сервисов на уроках математики. Методические рекомендации по использованию избранными онлайн сервисами отражены в разработанном электронном курсе «Интернет ресурсы для создания учебного и игрового контента по математике для младших школьников».

К л ю ч е в ы е с л о в а: ИКТ, дистанционное обучение, онлайн сервисы, младшие школьники

Svitlana Skvortsova, Tetiana Britskan

\section{Organización del aprendizaje matemático a distancia en la escuela primaria}

$$
\text { Resumen }
$$

El artículo está dedicado a investigar el problema del uso de las TIC por parte de los profesores de primaria en la enseñanza de las matemáticas, en particular durante el aprendizaje a distancia provocado por la pandemia de COVID-19. Los resultados del análisis comparativo de los servicios en línea más comunes se presentan en tres categorías: 1) servicios para la creación de un aula virtual y ejercicios interactivos, y otros contenidos educativos (LearningApps, Google Classroom, Classtime y Classdojo); 2) servicios para organizar una clase a distancia (Padlet); 3) servicios para la realización de una clase a distancia en forma de conferencia (Zoom, Skype, Microsoft Teams). Se presentan los resultados generalizados de la encuesta en línea a profesores de escuelas prima- 
Organization of Mathematical Distance Learning in Primary School

rias de Ucrania sobre el uso de estos servicios en línea en las lecciones de matemáticas. Además, las recomendaciones metodológicas para el uso de determinados servicios en línea se reflejan en el curso en línea desarrollado «Recursos de Internet para crear contenido de aprendizaje y juegos matemáticos para niños de primaria».

Palabras clave: TIC, educación a distancia, servicios en línea, escolares de primaria 